DOI: 10.30842/ielcp230690152414

Chaja V. Duerrschnabel

(University of Bern, Switzerland)

\title{
GREEK AND LATIN DEFIXIONES AND PRAYERS FOR JUSTICE WITHIN THE CONTEXT OF MEDITERRANEAN RITUAL TEXTS
}

Хая В. Дюрршнабель (Университет Берна, Швейцария)

\section{Греческие и латинские таблички с проклятиями и с «мольбами о справедливости» в контексте средиземноморских ритуальных текстов}

На свинцовых табличках античности писали два типа текстов:

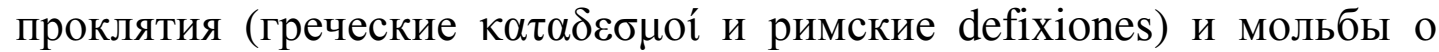
справедливости. Тексты, хотя и написаны на одном и том же материале, различаются по содержанию, структуре и формулам. Автор предлагает сравнить с текстами на внутренней поверхности так называемых магических чаш VI-VIII в. н. э., написанных на иудейсковавилонском арамейском языке, и высказывает предположение о близости структуры этих текстов к античным «мольбам о справедливости».

Ключевые слова: греческие, латинские и семитские ритуальные тексты, таблички с проклятиями, иудейско-вавилонский арамейский.

The present paper aims to analyze a corpus of selected Greek and Latin lead tablets within the context of Mediterranean ritual texts. As pointed out by H. S. Versnel (e. g. Versnel 2009), lead tablets inscribed in Greek and Latin can be subdivided into two groups, namely curse texts, commonly known as $\kappa \alpha \tau \delta \varepsilon \sigma \mu \mathrm{or}$ or defixiones, and prayers for justice. Although both groups share the same writing material, they show striking differences regarding content, terminology and formulaic structure. Both curse texts and prayers for justice address supernatural powers, but do so from different perspectives. Whereas curse texts address lower supernatural powers and order them to act accordingly, prayers for justice address higher divine powers and beg them for justice. Whilst curse texts are future-oriented and try to change an action that was not yet executed, prayers for justice notify divine powers of malevolent actions that have already been committed. Whereas curse texts are anonymous and give no justification, prayers for justice display the name of the aggrieved party and give a 
justification. Further, prayers for justice use an elaborated language and display striking parallels to legal texts and petitions.

As already assumed by $\mathrm{H}$. S. Versnel, both curse texts and prayers for justice were not only used within the Graeco-Roman world (Versnel 2009). Therefore, the present paper does not only aim to analyze selected lead tablets written in Greek and Latin, but also to contrast them with Latin Antique incantation bowl texts written in Jewish Babylonian Aramaic. D. Levene identified a special subgroup of these texts as curse texts (Levene 2013). However, the present paper argues that this subgroup should not be denominated as curse texts, but rather considered as prayers for justice according to Versnel's terminology. These incantation bowl texts do display a formulaic language that is very similar to that of the lead tables. By comparing the two, apparently unrelated copora, the present paper will give new impulses for the study of Greek, Latin and Semitic ritual texts.

Keywords: Greek, Latin and Semitic ritual texts, curse texts, Greek and Latin lead tablets, the Jewish Babylonian Aramaic language.

\section{Bibliography}

Levene, D. 2013: Jewish Aramaic Curse texts from Late-Antique Mesopotamia. Leiden; Boston.

Versnel, H. S. 2009: Fluch und Gebet. Berlin; New York. 